\title{
Studies on Well-Being of Urban Residents from the Perspective of Green Growth-Based on Empirical Analysis on Residents in Chengdu City of Western China
}

\author{
Yuan $\mathrm{Wei}^{1} \&$ Xu Guanjun ${ }^{2}$ \\ ${ }^{1}$ Economics Department, Sichuan Administration Institute, Chengdu, China \\ ${ }^{2}$ Business School, Beijing Normal University, Beijing, China \\ Correspondence: Yuan Wei, Economics Department, Sichuan Administration Institute, No.43,Guanghuacunjie Street, \\ Qing yang District, Chengdu City, Sichuan Province, China. Tel: 86-138-8086-7092. \\ Project supported: Major Program of the National Social Science Foundation of China (Grant No.14ZDA035), Sichuan \\ Administration Institute Young Scholars Fund (Grant No. QN2014003).
}

Received: January 21, 2016

Accepted: February 14, 2016

Available online: February 26, 2016

doi:10.11114/aef.v3i2.1417

URL: http://dx.doi.org/10.11114/aef.v3i2.1417

\begin{abstract}
In this paper, we make empirical analysis on the well-being of urban residents and its influencing factors from the perspective of green growth by using the survey data from the studying team which made the Urban Green Growth and Public Well-Being Investigation on 19 jurisdictional counties (districts and cities) of Chengdu City in August, 2015. The results suggest that residents' well-being has obvious regional differences, and the main city zone has the lowest green well-being while the third city cycle-layer has the highest green well-being. From the view of internal influencing factors of the resident well-being, the results show that age and income are positively correlated with the residents' green well-being, and the former correlation is significant, while residents' well-being of Chengdu is negatively correlated with the educational level. From the view of external influencing factors, green cover percentage, air quality and water quality are positively correlated with the residents' green well-being, while waste treatment and amount of factory have no significant correlations with residents' green well-being.
\end{abstract}

Keywords: green growth, urban residents' well-being, Chengdu City of Western China

\section{Introduction}

Cities are incubators of modern civilization, and habitat spaces human beings depend on. Since the reform and opening-up, the urbanization process in China has made remarkable achievements after the fast growth for more than 30 years, which brings much positive influence to the urban residents. However, with the faster and faster urbanization, the contradictions among resources, environment and urban economic growth become more and more serious. Nowadays, many cities are obsessed by "City Disease", and the well-being of urban residents hasn't been promoted at the same rate with the growth of income and urban economics, meaning there exists "Easterlin Paradox" (Easterlin, 1974) to some extent. Since the 18th National Congress of the Communist Party of China, the Party Central Committee puts more emphasis on following the new path of urbanization, at the same time, proposing the concept of "Green Growth", making the direction and goal of China's urban development further clearer. Under this background, considering China's national situation comprehensively, combining theories with practical regional development, promoting urban green growth and improving residents' well-being are not only important and key problems in China's national development strategy calling for urgent solutions, but also they have pretty high theoretical value and practical significance.

From the present literatures, the research on relationship between urban green growth and residents' well-being is still in the exploring stage. Some scholars mainly study the effect of environment and climate change on residents' well-being, which provides researching the relationship between urban economic growth and residents' well-being a green perspective. Scholars have found that human activity brings great impact on environment, and we need to understand the effect that environment pollution brings to human well-being much more deeply and comprehensively (Daniel Kahneman, 2006). Carroll (2009) found that after controlling the variables of individual characteristics and season, the 
drought condition could cause large psychological cost by using the quarterly data of 2001-2004 from Australia Statistical Bureau and survey data form 2435 areas. Diener.E (2010) conducted the research using the data from 16 European countries during 1973-1998 and drawn the conclusion that flood disaster could cause negative influence on subjective well-being, and Luechinger (2009) found the same result by researching the flood disaster. The research on urban economic growth and residents' well-being mainly focus on the influence on well-being caused by city size and residential environment. Morrison (2007) researched the relationship between city characteristics and subjective well-being, and he holds that after controlling the personal factors which influence well-being, city characteristics have independent influence on well-being. Knight and Gunatilaka (2007) made analysis on survey data from China rural and urban areas, and they found that rural residents' subjective well-being was high than urban residents though the per capita income of urban residents were triple of rural residents'.

Chinese and foreign scholars' research on green growth and residents' well-being provide beneficial references for us. However, in all, the research on theories of urban green growth just start, and studies on residents' well-being also have some limitations. Besides, the research on urban green growth and residents' well-being is still in the exploring stage, which needed to be studied further. Recent years, scholars have made extensive studies on the effects of economic factors on subjective well-being, but the factor urban environment quality hasn't been given ample attention which is an important factor influences life satisfaction. Especially under the background of global green economic growth, it's necessary to study the way urban green growth influences residents' well-being. And there is lack of practical support for promoting urban green growth and improving residents' well-being. So this paper can provide much realistic value for the analysis of urban green growth and residents' well-being.

This paper is based on questionnaire data, taking 19 jurisdictional counties (districts and cities) of Chengdu City (Note 1) as research objects, analyzing urban residents' well-being and its influencing factors from the perspective of green growth, taking Chengdu City as the sample to provide scientific basis for drafting and implementing Western City Green Development Strategy and references for urban green development.

\section{Research Methods and Comments on Results}

Generally, the most common method of measuring residents' well-being is forming self-reports by questionnaires. Though this method is pretty subjective, research shows that this kind of subjective experience data can effectively reflect the residents' real attitude towards well-being to some extent. In August 2015, the studying team conducted the survey "Urban Green Growth Public Well-being" in 19 jurisdictional counties (districts and cities) of Chengdu City getting 10 valid questionnaires at each investigation point and the final amount of valid questionnaire was 190. The studying team managed to investigate the situation of urban green growth and residents' subjective well-being through questionnaires. In the questionnaire, the score represents the feeling of well-being, and score 9 is the highest while score 0 is the lowest. The survey mainly investigated 8 aspects' influence on residents' well-being, which consists of green cover percentage, air quality, waste treatment, noise pollution, traffic jam situation, amount of factory, vehicle emissions and water quality situation. The studying team used the method of random checking and got sample population of the investigation. The basic situations of respondents are shown in table 1.

Table 1 Descriptive Statistics of the Investigation Sample

\begin{tabular}{cccc}
\hline Variable & Category & Frequency & Percentage \\
\hline \multirow{4}{*}{ Age } & $18-30$ & 54 & 28.42 \\
& $31-45$ & 89 & 46.84 \\
& $46-60$ & 34 & 17.89 \\
& Above 60 & 13 & 6.84 \\
\hline & Junior middle school & 29 & 15.26 \\
Educational & and below & & \\
Level & High school and & 45 & 23.68 \\
& Secondary school & 91 & 47.89 \\
& Undergraduate & 25 & 13.16 \\
\hline \multirow{4}{*}{ Income } & Master and above & 75 & 39.47 \\
& 1000-3000 yuan & 70 & 36.84 \\
& 3000-5000 yuan & 33 & 17.37 \\
& 5000-7000 yuan & 12 & 6.32 \\
\cline { 2 - 4 } & 7000 yuan and above & &
\end{tabular}

From results of questionnaires, we make specific analysis on scores of residents' well-being in Chengdu City and the eight aspects of well-being. The results are shown in the table 2 . 
Table 2. The Scores of Urban Green Growth Well-Being in Chengdu

\begin{tabular}{|c|c|c|c|c|c|c|c|c|c|}
\hline Districts & $\begin{array}{c}\text { Green } \\
\text { Cover } \\
\text { Percentag } \\
\text { e }\end{array}$ & $\begin{array}{c}\text { Air } \\
\text { Qualit } \\
y\end{array}$ & $\begin{array}{c}\text { Waste } \\
\text { Treatmen } \\
\mathrm{t}\end{array}$ & $\begin{array}{c}\text { Noise } \\
\text { Pollutio } \\
\text { n }\end{array}$ & $\begin{array}{c}\text { Traffic } \\
\text { Jam } \\
\text { Situatio } \\
\text { n }\end{array}$ & $\begin{array}{l}\text { Amoun } \\
\mathrm{t} \text { of } \\
\text { Factory }\end{array}$ & $\begin{array}{c}\text { Vehicle } \\
\text { Emission } \\
\text { s }\end{array}$ & $\begin{array}{c}\text { Water } \\
\text { Qualit } \\
y\end{array}$ & $\begin{array}{c}\text { Green } \\
\text { Growth } \\
\text { Well-Bein } \\
\mathrm{g}\end{array}$ \\
\hline $\begin{array}{l}\text { Jinjiang } \\
\text { Dist. }\end{array}$ & 7.51 & 7.23 & 7.58 & 7.18 & 7.12 & 7.31 & 7.22 & 7.94 & 7.39 \\
\hline $\begin{array}{l}\text { Qingyang } \\
\text { Dist. }\end{array}$ & 7.49 & 7.24 & 7.56 & 7.21 & 7.21 & 7.29 & 7.25 & 7.94 & 7.40 \\
\hline Jinniu Dist. & 7.50 & 7.33 & 7.58 & 7.21 & 7.31 & 7.28 & 7.31 & 7.93 & 7.43 \\
\hline Wuhou Dist. & 7.55 & 7.41 & 7.62 & 7.23 & 7.39 & 7.27 & 7.38 & 7.96 & 7.48 \\
\hline $\begin{array}{l}\text { Chenghua } \\
\text { Dist. }\end{array}$ & 7.56 & 7.43 & 7.61 & 7.24 & 7.44 & 7.21 & 7.41 & 7.97 & 7.49 \\
\hline $\begin{array}{c}\text { The First } \\
\text { City } \\
\text { Cycle-Layer }\end{array}$ & 7.52 & 7.33 & 7.59 & 7.21 & 7.29 & 7.27 & 7.31 & 7.95 & 7.44 \\
\hline $\begin{array}{l}\text { Longquanyi } \\
\text { Dist. }\end{array}$ & 7.54 & 7.47 & 7.61 & 7.25 & 7.49 & 7.17 & 7.45 & 7.96 & 7.49 \\
\hline $\begin{array}{l}\text { Qingbaijian } \\
\text { g Dist. }\end{array}$ & 7.55 & 7.48 & 7.63 & 7.26 & 7.49 & 7.26 & 7.46 & 7.97 & 7.51 \\
\hline $\begin{array}{l}\text { Shuangliu } \\
\text { County }\end{array}$ & 7.56 & 7.42 & 7.62 & 7.23 & 7.47 & 7.28 & 7.45 & 7.97 & 7.50 \\
\hline $\begin{array}{l}\text { Wenjiang } \\
\text { Dist. }\end{array}$ & 7.62 & 7.47 & 7.63 & 7.33 & 7.50 & 7.35 & 7.45 & 7.99 & 7.54 \\
\hline Pi County & 7.62 & 7.48 & 7.65 & 7.31 & 7.50 & 7.30 & 7.46 & 7.97 & 7.53 \\
\hline Xindu Dist. & 7.70 & 7.49 & 7.67 & 7.37 & 7.56 & 7.32 & 7.46 & 8.00 & 7.57 \\
\hline $\begin{array}{c}\text { The Second } \\
\text { City } \\
\text { Cycle-Layer }\end{array}$ & 7.60 & 7.47 & 7.64 & 7.29 & 7.50 & 7.28 & 7.46 & 7.98 & 7.52 \\
\hline $\begin{array}{l}\text { Jintang } \\
\text { County }\end{array}$ & 7.72 & 7.51 & 7.71 & 7.37 & 7.57 & 7.43 & 7.51 & 8.04 & 7.61 \\
\hline Dayi County & 7.78 & 7.44 & 7.70 & 7.45 & 7.59 & 7.40 & 7.51 & 8.03 & 7.61 \\
\hline $\begin{array}{l}\text { Pujiang } \\
\text { County }\end{array}$ & 7.73 & 7.35 & 7.65 & 7.44 & 7.59 & 7.32 & 7.45 & 7.98 & 7.56 \\
\hline $\begin{array}{l}\text { Xinjin } \\
\text { County }\end{array}$ & 7.73 & 7.26 & 7.64 & 7.35 & 7.57 & 7.22 & 7.40 & 7.96 & 7.52 \\
\hline $\begin{array}{c}\text { Dujiangyan } \\
\text { City }\end{array}$ & 7.79 & 7.30 & 7.55 & 7.39 & 7.56 & 7.25 & 7.35 & 7.90 & 7.51 \\
\hline $\begin{array}{c}\text { Pengzhou } \\
\text { City }\end{array}$ & 7.66 & 7.14 & 7.44 & 7.20 & 7.48 & 7.02 & 7.24 & 7.81 & 7.37 \\
\hline $\begin{array}{l}\text { Qionglai } \\
\text { City }\end{array}$ & 7.68 & 7.67 & 7.65 & 7.34 & 7.61 & 7.25 & 7.21 & 8.09 & 7.56 \\
\hline $\begin{array}{c}\text { Chongzhou } \\
\text { Ctiy }\end{array}$ & 7.91 & 7.60 & 7.75 & 7.40 & 7.41 & 7.51 & 7.33 & 7.90 & 7.60 \\
\hline $\begin{array}{c}\text { The Third } \\
\text { City } \\
\text { Cycle-Layer }\end{array}$ & 7.75 & 7.41 & 7.64 & 7.37 & 7.55 & 7.30 & 7.38 & 7.96 & 7.54 \\
\hline $\begin{array}{l}\text { Chengdu } \\
\text { City }\end{array}$ & 7.64 & 7.41 & 7.62 & 7.30 & 7.47 & 7.29 & 7.38 & 7.96 & 7.51 \\
\hline
\end{tabular}

As it's shown in table 2, in the view of comprehensive scores on well-being, Chengdu residents' average green well-being score is 7.51, and regional differences are relatively significant. Green well-being of Jintang County and Dayi County which both situate in the first city cycle-layer are the highest, while Jinjiang District, Qingyang District in first cycle-layer and Pengzhou City in third cycle-layer have the lowest scores. In fact, according to the traditional division way that divides the city cycle-layers based on their distance from the main city zone, the third city cycle-layer which is farthest from the central city gains the highest score on green well-being, and the second city cycle-layer's 
score on well-being takes the second place while the first cycle-layer has the lowest well-being. In the view of eight aspects of green growth, residents in Chengdu are most satisfied with water quality and the score on this aspect is 7.96, while the residents are most dissatisfied with the amount of factory and noise pollution, and the scores are 7.29 and 7.30 respectively.

In the view of eight aspects of resident green growth well-being, the satisfaction on green cover percentage becomes higher and higher from the first city cycle-layer to the third. The satisfaction on air quality shows the same trend as the green cover percentage, but Pengzhou City in third cycle-layer gains relatively low score on air quality making the whole third city cycle-layer get a lower score than normal. Besides, the situations of water quality and vehicle emissions of the second cycle-layer are better than the other two cycle-layers, while the third city cycle-layer gains the highest satisfaction on noise pollution, traffic jam situation and amount of factory.

The main reason that accounts for great regional differences on resident green well-being is that the main city zone of Chengdu contributes $46.8 \%$ of the city's total GDP while covers $15 \%$ of the land. It indicates the economic disparity among urban areas in Chengdu and the city-rural system exists. On account of main industries, transportation hubs, large enterprises and public service departments mainly centralizing in central city, the suburb areas can only develop basic agricultural and low-end industries providing material products for the main city zone and the industrial structure in suburb area is single, leading that the employed population gather intensively in the central region. Though the suburb areas have inexpensive land and much more abundant labor force, the transportation isn't convenient enough and level of labor quality isn't high making the industrial structure in a backward state. At the main time, the income gap between city and rural is greatly significant, directly reflecting the imbalance of urban and rural individual economic wealth. Otherwise, industries and human resources of central region occupy the leading position for a long time, and disparity on economic resource is notable, finally leading significant regional differences on resident green well-being among there city cycle-layers.

\section{Analysis on Influencing Factors}

Residents' well-being in the process of urban green growth is affected by various factors. In this paper, we conduct analysis from internal factors and external factors. The internal factors mainly refer to the respondents' income, age and educational level, while the external factors consist of green cover percentage, air quality, waste treatment, noise pollution, traffic jam situation, amount of factory, vehicle emissions and water quality. According to the instructions for respondents before conducting the survey, when the score is lower than 7, it represents dissatisfaction, while the score is at 8 or higher, it means satisfaction, and if the score is at 7 or higher than 7 but lower than 8 , it's near satisfaction.

\subsection{Analysis on Internal Influencing Factors}

Urban residents' green well-being can be affected by age, educational level and income, and in this paper we make statistical analysis on these three factors respectively.

The table 3 shows the relationships between green well-being of Chengdu with age, income and educational level. In the factor of age, residents aged higher than 60 gain the highest well-being, while the residents aged among 31 to 45 have the lowest well-being. In general, the portion of satisfaction on city green growth becomes higher accompanied by the increase of age. In the factor of educational level, with the promotion of educational level, the portion of residents' satisfaction on city green growth decreases from $20.69 \%$ to $12 \%$, and the dissatisfaction rate increases from $10.34 \%$ to $36.00 \%$. In the factor of income, the group whose monthly salary are among 5000 yuan to 7000 yuan gain the highest green well-being, and in general, the satisfaction rate improves as the salary increases.

Considering that the statistical analysis can't show the relationship between urban green growth and resident well-being intuitively, we conduct chi-square tests to verify the independent relationships or correlations between demographic variables and surrounding environment, and use analysis to determine the correlation degree and directions of the relationships.

As it's shown in table 4, the urban green well-being of Chengdu is positively correlated with age. There are some reasons account for this phenomenon, for one thing that the less aged group knows more about policies on protecting environment and implementation situation of the government protection, and this group can get more information making they have higher expectations and more dissatisfactions, so the less aged population satisfaction rate is lower. For another thing, the old group has higher level of tolerance and lower sensitivity making they have higher assessment on the environment. 
Table 3. Relationships between Green Growth Well-Being of Chengdu with Age, Educational Level and Income

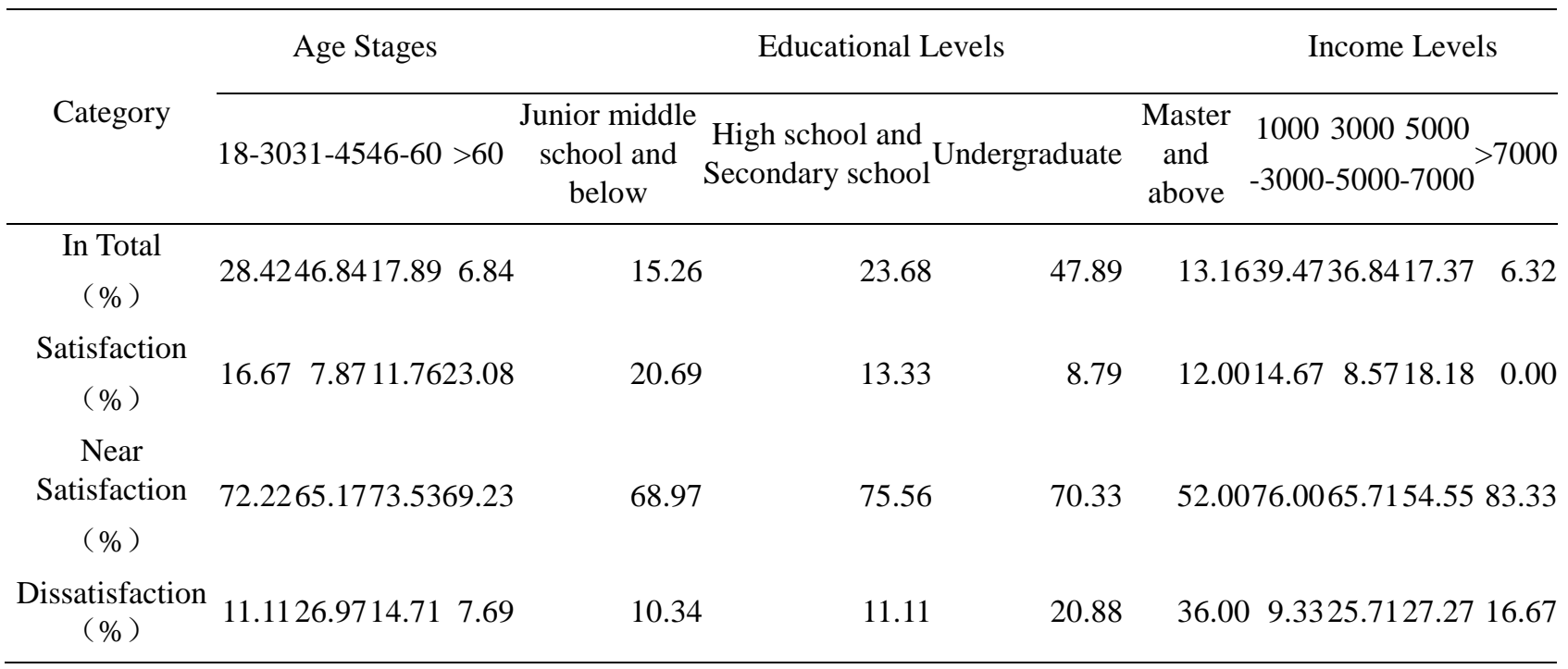

Table 4. Chi-Square Tests between Green Growth Well-Being of Chengdu with Age, Educational Level and Income

\begin{tabular}{|c|c|c|c|c|}
\hline \multirow{3}{*}{ Chengdu City } & Age & $\begin{array}{c}\text { Probability Value } \\
\text { Correlation } \\
\text { Coefficient }\end{array}$ & $\begin{array}{c}0.029 \\
14.0186\end{array}$ & $\begin{array}{l}\text { Significant } \\
\text { Positive } \\
\text { Correlation }\end{array}$ \\
\hline & Educational Level & $\begin{array}{c}\text { Probability Value } \\
\text { Correlation } \\
\text { Coefficient }\end{array}$ & $\begin{array}{c}0.047 \\
-12.7748\end{array}$ & $\begin{array}{c}\text { Significant } \\
\text { Negative } \\
\text { Correlation }\end{array}$ \\
\hline & Income Level & $\begin{array}{c}\text { Probability Value } \\
\text { Correlation } \\
\text { Coefficient }\end{array}$ & $\begin{array}{c}0.006 \\
17.9697\end{array}$ & $\begin{array}{l}\text { Significant } \\
\text { Positive } \\
\text { Correlation }\end{array}$ \\
\hline
\end{tabular}

As we can see in the table 4, residents' well-being decreases when the educational level improves, and this conclusion can also be reflected from the feedback of the respondents. The group whose educational level is higher can get more direct or indirect information about the environmental protection, and knows more about government environmental protection planning and its implementation effect, so it's easy for this group to make comprehensive evaluation of the environment issue. On the contrary, the group whose educational level is lower tends to make superficial assessments relying on perceptual knowledge of surrounding environment. The green growth well-being of Chengdu is positively correlated with income, indicating that the group whose income is higher tends to choose to even change the surrounding environment of his life to gain higher well-being.

\subsection{Analysis on External Influencing Factors}

There are many external factors that influence the green growth well-being, and in this paper we make analysis from eight aspects which includes green cover percentage (represented by Green), air quality situation (represented by Air), waste treatment (represented by Rubbish), noise pollution (represented by Noise), traffic jam situation (represented by Traffic), amount of factory (represented by Factory), vehicle emissions (represented by Emissions) and water quality (represented by Water). And we set the regression model as follows:

$$
\begin{array}{r}
Y_{i}=\beta_{0}+\beta_{1} \text { Green }+\beta_{2} \text { Air }+\beta_{3} \text { Rubbis } h+\beta_{4} \text { Noise }+\beta_{5} \text { Traffic }+\beta_{6} \text { Factory } \\
+\beta_{7} \text { Emissions }+\beta_{8} \text { Water }+\mu_{i} \\
\mathrm{i}=1,2, \ldots, \mathrm{n}
\end{array}
$$

In our research, we use STATA10.0 software to make a regression analysis. This model's coefficient of determination is 0.6761 , meaning that the fitting degree is high, and specific results are shown is table 5. 
Table 5. Results of Green Growth Well-Being Regression Model

\begin{tabular}{ccc}
\hline Explained Variable & $\begin{array}{c}\text { Explanatory } \\
\text { Variable }\end{array}$ & $\begin{array}{c}\text { Influence } \\
\text { Coefficients(Note 2) }\end{array}$ \\
\hline & Green & $0.359\left(^{*}\right)$ \\
& Air & $0.355(* *)$ \\
Green growth resident well-being & Rubbish & -0.818 \\
of Chengdu & Noise & $-0.211\left(^{*}\right)$ \\
& Traffic & $-0.464\left(^{* *}\right)$ \\
& Factory & 0.502 \\
& Emissions & $-0.268\left(^{*}\right)$ \\
& Water & $0.242(*)$ \\
\hline
\end{tabular}

From table 5 we can see the results of the regression, and the explanations are as follow:

(1) The research result shows that green cover percentage has positive effect on resident green well-being, meaning that as green cover percentage becomes higher, resident green well-being increases to some extent.

(2) Air quality also has positive effect on resident green well-being, and with the air quality increasing, residents' well-being rises significantly.

(3) The result shows that the relationship between waste treatment and resident well-being doesn't pass the significance test, which means that residents are insensitive to the well-being from waste treatment.

(4) We can see from the result that residents' green well-being is negatively correlated with noise pollution, and with the issuance of noise pollution control measures, the remission of noise can greatly improve residents' well-being.

(5) In all external influencing factors, traffic jam situation has significant effect on resident green well-being as well as air quality, and as the most intuitive factor in residents' daily life, traffic jam situation affects residents' green well-being significantly that indicates alleviating traffic jam can improve residents' well-being greatly.

(6) Vehicle emissions has negative effect on residents' green well-being, and the more the vehicle emission, the lower the residents' green well-being.

(7) Water quality influences residents' green well-being remarkably, and the improvement of water quality can enhance the residents' well-being.

(8) We can see from the result that the relationship between amount of factory and resident well-being doesn't pass the significance test, and the main reason is that factories mostly situate in industrial parks which are far away from residents' living areas. Besides, the increase of factories can affect residents' green well-being indirectly by other ways such as air quality, noise pollution, traffic jam situation and vehicle emissions leading that residents can't feel the negative influence from the increase of factories obviously.

\section{Conclusions}

Chengdu City of Western China, as "Center of Technique, Trade, Financial and Communication \& Transportation Hub" designated by State Council, is the window of Western China and it strengthens environment protection at the same time in recent years. However, facing the severe pressure of environment resources, it's imperative to enhance the urban green growth and improve residents' green well-being. From the research in this paper, we find that residents' green well-being in Chengdu has obvious regional differences. The first city cycle-layer as the main city zone has the lowest green well-being, while the third city cycle-layer which is furthermost from the main city zone has the highest green well-being. In the view of internal factors that influence resident green well-being, the empirical results show that urban green well-being of Chengdu is positively correlated with age and income, while negatively correlated with educational level. In the view of external influencing factors, residents' well-being has positive correlations with green cover percentage, air quality, and water quality, while negatively correlated with noise pollution, traffic jam situation and vehicle emissions.

During the period of The Thirteenth Five-Year Plan, Chengdu City should establish the development idea of urban green growth much further, put emphasize on improving residents' green well-being, strengthen the foundation of advantage resources, try to enhance the quality of city and urban carrying capacity, improve functions of regional center urban, complete the transition of city growth from chasing for output capacity merely to pursuing for urban 
development quality and benefits. Besides, Chengdu City should pay more attention to improving the central city's function as green rural living area, developing the green cycle industries, enhancing the environment treatments, saving energy, water and resource to the maximum limit, providing safe, healthy, environmental and efficient working and living spaces for residents, and building an environmental friendly and human-oriented city eventually.

\section{References}

Daniel, K., \& Alan, B. K. (2006). Developments in the Measurement of Subjective Well-being. The Journal of Economic Perspectives, 20, 3-24

Diener, E. (2000). Subjective well-being: The science of happiness and a proposal for a national index. American Psychologist, 1,34-43.

Easterlin, R. A. (1974). Does Economic Growth Improve the Human Lot? Some Empirical Evidence[A]. In: Paul A. David and MelW. Reder, eds.Nations and Households in Economic Growth:Essays in Honour of Moses Abramovitz[C]. New York: Academic Press.

Knight, S., \& Gunatilaka. (2009). Subjective well-being and its determinants in rural China, China Economic Review, $4,635-649$.

Liu, J. Q., Xiong, M. L., \& Su, Y. (2012). National Sense of Happiness in the Economics Growth Period: A Study Based on CGSS Data. Social Sciences in China, 2012(12), 82-208.

Lu, Y. P., \& Wang, T. (2010). Research Review on Subjective Well-Being Influencing Factors. Economic Perceptives, 2010(5), 125-130.

Luo, C. (2009). Absolute Income, Relative Income and Subjective Well-being: Empirical Test Based on the Sample Data of Urban and Rural Households in China. Journal of Finance and Economics. 2009(11), 79-91.

Pedro, C. C. (2013). Research Review on Subjective Well-being. Foreign Theoretical Trends, 7.

Tian, G. Q., \& Yang, L. (2006). A Solution to Happiness-Income Puzzle: Theory and Evidence. Economics Research Journal, 2006(11), 4-15.

\section{Notes}

Note 1. According to traditional methods, we divide the city cycle-layers based on their distance from main city zone. The first city cycle-layer includes Jinjiang District, Qingyang District, Jinniu District, Wuhou District and Chenghua District, while the second city cycle-layer consists of Longquanyi District, Qingbaijiang District, Shuangliu County, Wenjiang District, Pi County and Xindu District. The third city cycle-layer consists of Jintang County, Dayi County, Pujiang County, Xinjin County, Dujiangyan City, Pengzhou City, Qionglai City and Chongzhou City.

Note $2 . * * *, * *, *$ represents significant at the level of $1 \%, 5 \%$ and $10 \%$ respectively

\section{$($ (c) $)$ EY}

This work is licensed under a Creative Commons Attribution 3.0 License. 